Acta vet. scand. $1973,14,347-349$.

Brief Communication

\title{
EXCRETION OF IODIDE (131I) DURING ADMINISTRATION OF INACTIVE IODIDE IN CATTLE
}

In studies with radioiodinated proteins knowledge on the excretion rate of iodide is important, when the thyroid uptake of radioiodide is impeded by administration of inactive iodide.

The excretion of ${ }^{131}$ I was studied on 4 experiments in 3 calves (Table 1). A dose of approx. $1,000 \mu \mathrm{Ci}\left(\mathrm{Na}^{131} \mathrm{I}\right)$ was injected

Table 1. Excretion of sodium iodide (131) in cattle during administration of inactive iodide.

\begin{tabular}{lcccccc}
\hline J. no. & $\begin{array}{c}\text { Age } \\
\text { (months) }\end{array}$ & $\begin{array}{c}\text { Weight } \\
(\mathbf{k g})\end{array}$ & $\begin{array}{c}\mathrm{T}_{\frac{1}{2}} \\
(\text { days })\end{array}$ & $\begin{array}{c}\mathbf{k}_{\mathbf{p}} \\
\text { (days-1) }\end{array}$ & $\begin{array}{c}\text { Radioactivity ratios } \\
\text { tear/plasma }\end{array}$ & saliva/plasma \\
\hline 181 & 15 & 412 & 1.8 & 0.39 & 1.1 & 0.19 \\
182 & 13 & 333 & 1.6 & 0.43 & 1.3 & 0.23 \\
183 & 14 & 367 & 1.3 & 0.53 & 1.1 & 0.18 \\
183 & 15 & 395 & 1.2 & 0.58 & 1.3 & 0.22 \\
\hline
\end{tabular}

into the jugular vein. Every day 2 doses of $8 \mathrm{ml}$ Lugol's iodine solution were given perorally starting 2 days prior to the injection. This is a usual dose of inactive iodide in tracer studies (Nielsen 1966, Nansen 1970). Blood, saliva and tear samples were taken 15, 30 and $60 \mathrm{~min}$. and $2,3,4,5,6,12,24,36,48,60$, 72, 84 and $96 \mathrm{hrs}$. after the injection. Saliva, which mainly consisted of parotid secretion, was obtained according to Skydsgaard (1967). Tear fluid was obtained from the lower conjunctival sac by means of a $1,000 \mu \mathrm{l}$ constriction pipette. At the completion of each experiment the radioactivity of the plasma, saliva and tear samples was measured in a thallium-activated $\mathrm{NaI}$ scintillation well-counter. A rate constant $\left(k_{p}\right)$ for the removal of ${ }^{131} \mathrm{I}$ from the plasma was calculated from the equation $\mathrm{k}_{\mathrm{p}}=$ $\frac{\ln 2}{T_{1}}$, where $T_{\frac{1}{2}}$ is the half-life of the plasma disappearance curve (Fig. 1). 


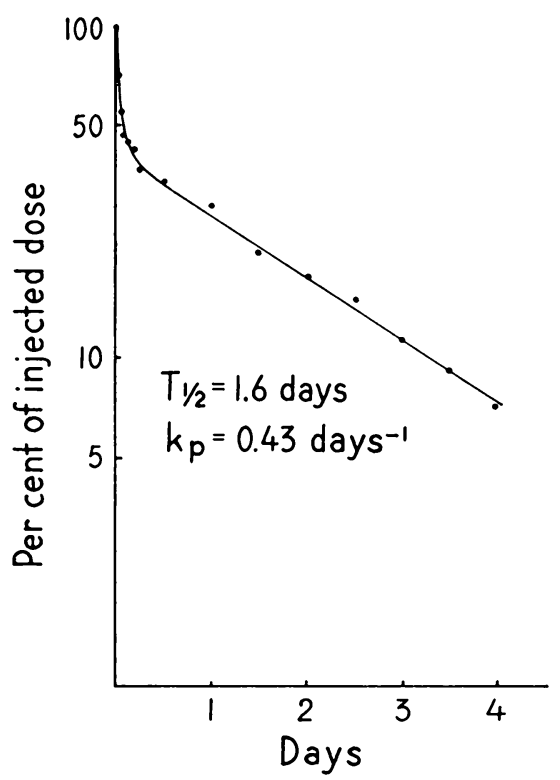

Figure 1. Plasma disappearance curve of sodium iodide (131I) during administration of inactive iodide (J. no. 182).

The rate constant for the disappearance of ${ }^{131}$ I from the plasma varied from 0.38 to 0.58 days $^{-1}$ (Table 1). This is in agreement with the results of Sørensen (1958) obtained in studies during which thyroid uptake was not impeded. In man Rossing \& Andersen (1965) found a higher rate constant for the disappearance of ${ }^{131} \mathrm{I}$, i. e. $\mathrm{k}_{\mathrm{p}}=1.6$ days $^{-1}$.

Injection of a denaturated radioiodinated protein results in a rapid liberation of a high amount of iodide into the circulation. Due to the rapid excretion of iodide in man (Rossing \& Andersen) an unusually high urinary excretion of radioactivity during the first day is considered to indicate denaturation of the labelled protein. In cattle such a denaturation will result in a more delayed excretion of radioiodide since the half-life of iodide in cattle, as shown in the present communication, is considerably longer than in man. Accordingly, in cattle the urinary excretion of radioactivity during the first day is not a useful criterion to indicate denaturation of the labelled protein.

The ratio between the radioactivity in tears and plasma was higher than the saliva to plasma radioactivity ratio (Table 1 ). It may be suggested that some secretion of iodide takes place in 
the lachrymal gland, since the radioactivity in tear samples was higher than in simultaneously drawn plasma samples. The results partly explain the high content of non-protein-bound radioactivity in bovine tears observed in studies on the transport of radioiodinated proteins from blood to tears (Pedersen 1973).

\section{K. B. Pedersen}

The Department of Special Pathology and Therapy, Royal Veterinary and Agricultural University, Copenhagen, Denmark.

\section{REFERENCES}

Nansen, P.: Metabolism of bovine immunoglobulin-G. A clinical and pathophysiological study. Thesis, Munksgaard 1970, pp. 33-37.

Nielsen, K.: Gastrointestinal protein loss in cattle. A clinical and pathophysiological study. Thesis, Carl Fr. Mortensen, Copenhagen 1966, p. 20.

Pedersen, $K$. B.: The origin of immunoglobulin-G in bovine tears. Acta path. microbiol. scand. Sect. B. 1973, 81, 245-252.

Rossing, N. \& S. B. Andersen: Renal excretion rate of ${ }^{131}$ I during administration of large doses of inactive iodide. In Physiology and Pathophysiology of Plasma Protein Metabolism. Proc. 3rd Symp. Switzerland 1964. Hans Huber Publ. Berne and Stuttgart 1965, pp. 116-121.

Skydsgaard, J. M.: En metode til diagnosticering af latent natriummangel i kvægbesætninger. Nord. Vet.-Med. 1967, 19, 346-349.

Sфrensen, P. Havskov: Jodstofskiftet og thyreoideafunktion hos kvæg og svin. Thesis, August Bangs Forlag, Copenhagen 1958, p. 71.

(Received February 13, 1973).

Reprints may be requested from: K. B. Pedersen, Department of Special Pathology and Therapy, Royal Veterinary and Agricultural University, Bülowsvej 13, DK-1870 Copenhagen V, Denmark. 